\title{
Mainstreaming Multi-Risk Approaches into Policy
}

\author{
Anna Scolobig ${ }^{1, *}$, Nadejda Komendantova ${ }^{1,2}$ and Arnaud Mignan ${ }^{3}$ \\ 1 Climate Policy Group, Department of Environmental Systems Science, \\ Swiss Federal Institute of Technology (ETH), 8092 Zürich, Switzerland; komendan@iiasa.ac.at \\ 2 Risk and Resilience Program, International Institute for Applied Systems Analysis (IIASA), \\ 2361 Laxenburg, Austria \\ 3 Institute of Geophysics, Swiss Federal Institute of Technology (ETH), 8092 Zürich, Switzerland; \\ arnaud.mignan@sed.ethz.ch \\ * Correspondence: anna.scolobig@usys.ethz.ch; Tel.: +41-44-632-4498
}

Received: 7 November 2017; Accepted: 6 December 2017; Published: 12 December 2017

\begin{abstract}
Multi-risk environments are characterized by domino effects that often amplify the overall risk. Those include chains of hazardous events and increasing vulnerability, among other types of correlations within the risk process. The recently developed methods for multi-hazard and risk assessment integrate interactions between different risks by using harmonized procedures based on common metrics. While the products of these assessments, such as multi-hazard and -risk indexes, maps, cascade scenarios, or warning systems provide innovative and effective information, they also pose specific challenges to policy makers and practitioners due to their novel cross-disciplinary aspects. In this paper we discuss the institutional barriers to the adoption of multi-risk approaches, summarizing the results of the fieldwork conducted in Italy and Guadeloupe and of workshops with disaster risk reduction practitioners from eleven European countries. Results show the need for a clear identification of responsibilities for the implementation of multi-risk approaches, as institutional frameworks for risk reduction remain to this day primarily single-risk centered. Authorities are rarely officially responsible for the management of domino effects between e.g., tsunamis and industrial accidents, earthquake and landslides, floods and electricity network failures. Other barriers for the implementation of multi-risk approaches include the limited measures to reduce exposure at the household level, inadequate financial capacities at the local level and limited public-private partnerships, especially in case of interactions between natural and industrial risks. Adapting the scale of institutions to that of multi-risk environments remains a major challenge to better mainstream multi-risk approaches into policy. To address it, we propose a multi-risk governance framework, which includes the phases of observation, social and institutional context analysis, generation of multi-risk knowledge and stakeholder engagement processes. Yet, more research is needed in order to test the framework and to identify the hallmark characteristics of effective multi-risk governance.
\end{abstract}

Keywords: multi-risk approach; domino effects; institutional barriers; governance; stakeholder engagement; multi-risk policy

\section{Introduction}

The Sendai Framework for Disaster Risk Reduction states that "disaster risk reduction practices need to be multi-hazard and multi-sectoral-based, inclusive and accessible in order to be efficient and effective" [1-6]. Consideration of interactions between risks can make a great difference not only to hazard, risk and vulnerability assessment but also to the related decision-making processes.

On the one side, reducing the vulnerability to one hazard may increase it for another one. For example, in Kobe, Japan, the reinforced concrete roofs made to resist cyclonic winds contributed to the increased vulnerability of these buildings during the 1995 earthquake. Building construction 
practices made use of heavy roofing materials to protect the buildings from heavy winds, a concern in a city periodically subjected to tropical cyclones. However, the heavy roofs, in turn, made the buildings more vulnerable to earthquake damage [2]. In California, USA, the earthquake proof houses built in wood made entire neighborhoods vulnerable to fires, as shown during the 2017 wildfires causing the evacuation of thousands and the displacement of more than 7000 households.

On the other side, synergies resulting in the mitigation of multiple risks can also occur. For example, with little additional investment, the cyclone shelters currently being constructed alongside the Indian Ocean could serve also as multi-purpose shelters for cyclones and tsunamis (ibid).

There is a growing awareness that contemporary disasters are an interactive mix of multiple natural, technological, and social events [3] and that considering interactions of risks and emerging cascading/domino effects is essential to improve risk management. On several occasions' inadequate and/or dysfunctional governance have exacerbated the negative consequences of cascading disasters and increased vulnerability. An example is the Fukushima disaster in 2011: a great offshore earthquake (magnitude 9, the largest in Japan's history) triggered a tsunami. The combination of these two events led to the joint failure of the Fukushima Daiichi nuclear power station. This event has been defined by the National Diet of Japan as a failure of risk governance [4] or, more properly, of multi-risk governance.

However, there is little research into (i) the added value of multi-risk in comparison to single risk governance and (ii) the hallmarks of multi-risk governance frameworks and policies. Early works tackling those issues include [5-7].

This paper explores the concept of multi-risk governance and discusses the institutional barriers related to its implementation. While new theories and methods for multi-risk assessment have been developed in the past decade (e.g., [8-13]), the same is not true for multi-risk governance [7]. There are many open issues related to this concept, its operationalization and implementation. First, the allocation of legal responsibilities for domino effects is not always clear. For example, although there are significant differences between countries, the sharing of responsibility between the public and private sector is especially unclear. Second, the lack of authorities responsible for reducing the risks generated by those domino effects is definitely a problem, along with difficulties in mainstreaming multi-risk governance into risk policies.

In this paper, we address the institutional barriers to the adoption of multi-risk approaches, summarizing the results of the fieldwork conducted in Italy and Guadeloupe and of workshops with disaster risk reduction practitioners from eleven European countries. On the basis of these results, we present a multi-risk governance framework that includes the phases of multi-risk environments observation, social and institutional context analysis, co-design of risk reduction options between experts and stakeholders, and implementation (based on the International Risk Governance Council IRGC risk governance framework by [14-16]). The paper ends by presenting future research directions aimed at testing the framework and identifying the hallmark characteristics of effective multi-risk governance.

\section{Background}

The adoption of a multi-risk approach is considered as a priority in a number of documents, especially at the international level. Calls for multi-hazard and risk approaches date back to the early 1990s, with the Agenda 21 for sustainable development. Agenda 21 emphasised the need of a "complete multi-hazard research" as a part of human settlement planning and disaster risk. This idea was further developed by other work, including the Hyogo Framework for Action [17] and the most recent Sendai Framework for Disaster Risk Reduction (SFDRR) [1].

The Hyogo Framework for Action (HFA) on disaster risk reduction [17] states that research methods and tools for multi-risk assessments should be developed and strengthened (priority 3, indicator 3.3) (In the evaluation of the implementation of HFA in Europe, the indicator 3.3, which deals with the development of tools for multi-risk assessment, received the lowest ranking among the indicators in the same group (i.e., priority 3 "use of knowledge, innovation and education 
to build a culture of safety and resilience at all levels")). The SFDRR 2015-2030 [1] calls to "promote investments in innovation and technology development in long-term, multi-hazard and solution-driven research in disaster risk management" [1-5], See also Section 1. It also strongly encourages the development of multi-hazard warning systems as well as multi-hazard, inclusive, science-based and risk informed decision-making.

Several policy documents referencing multi-risk approaches have also been used at the European level. For example, the Internal Security strategy developed by the European Commission (e.g., SEC (2010) 1626 Final) advocates for an "all-hazard approach to threat and risk assessment" and states that the EU Commission needs to develop the EU risk assessment and mapping guidelines for disaster management based on a multi-hazard and -risk approach. Similar statements can be found in the EU Community framework on disaster prevention (point 22: "The Council of EU underlines the usefulness of a multi-hazard approach to a Community disaster prevention framework"), in the Regulation 1313/2013/EU (EC, 2013), and in the European disaster risk reduction strategy (COM 2008, 130), which acknowledges the need of a comprehensive approach to disaster management. These documents are based on evidence provided by several European research projects (e.g., ARMONIA (Applied Multi-Risk Mapping of Natural Hazards for Impact Assessment), Na.R.As (Natural Risks Assessment Harmonisation of Procedures, Quantification and Information), MATRIX (New Multi-Hazard and Multi-Risk Assessment for Europe), STREST (Harmonized approach to stress tests for critical infrastructures against natural hazards), Fortress (Harmonized approach to stress tests for critical infrastructures against natural hazards), which are on-going since the 2000s, and aim to improve multi-risk assessment concepts and methods.

The expressed need for multi-risk approaches at the international level is not matched by policies, legislation, institutional frameworks, or implementation at national, regional and local levels. There might be several reasons for this. One of them is the novelty of the multi-risk scientific approach (see Section 2). Another one is the time needed for integration of innovation into the existing policy cycles. As a result, this science-policy divide can reduce capacity to respond effectively to cascading disasters and undermine effective multi-risk management.

To our knowledge there is no published literature with review of the implementation of multi-risk policies at national or local level, making it difficult to identify countries (if they exist), which officially embrace a multi-risk approach. Available scientific evidence on multi-risk policies and governance frameworks is also limited [5-7]. One of the reasons is that it is difficult for disaster risk reduction stakeholders to recognize the added value of adopting a multi-risk over the single-risk governance approach. So, is there a difference between single and multi-risk governance?

Risk governance is usually defined as various ways in which stakeholders (e.g., policy-makers, practitioners, infrastructure operators, insurance companies, researchers and the general public) manage their common risk issues [18-20]. There is a vast literature on risk governance (see e.g., [14,17,18,21-33] and while we do not aim to summarize it, we provide in the Appendix A a selection of approaches and frameworks which we consider particularly relevant for the research presented in this paper.

There are multiple governance benefits derived by the adoption of a multi-risk approach. For example, up to now, decision makers often prioritized the risks that could significantly be reduced and not necessarily those with the highest potential impacts [7]. Nor do they systematically take into account cascades and associated effects. A multi-risk approach allows comparing and ranking different risks, hence providing a holistic view of interactions and conflicts of risks (e.g., when reducing one risk increases another one), and improved accuracy on expected losses. This, in turn, shall improve urban planning, emergency management and ultimately, multi-risk governance [5,7]. Moreover addressing multiple hazards may lead to significant cost reductions, improvements in the efficiency of risk mitigation and management measures, and better identification of action priorities compared to cases when hazards are treated separately (ibid). Table 1 based on [5] provides a synthesis of the governance benefits derived by the adoption of a multi-risk approach. 
Table 1. Governance benefits derived by adoption of a multi-risk approach [5].

\begin{tabular}{|c|c|}
\hline Sector & Benefit \\
\hline Risk assessment and land use planning & $\begin{array}{l}\text { Consideration of cascading effects and interactions between } \\
\text { risks and inclusion in risk zoning and land use planning; } \\
\text { Comparison and ranking of different risks; } \\
\text { Identification of the highest risk in terms of potential impacts } \\
\text { (derived by multi-risk assessment); } \\
\text { Standardization across risk fields. }\end{array}$ \\
\hline Emergency management & $\begin{array}{l}\text { Development of multi-hazard and -risk scenarios in order to } \\
\text { manage emergency situations in real time; } \\
\text { Better preparedness due to knowledge of cascading effects. }\end{array}$ \\
\hline Risk mitigation & $\begin{array}{l}\text { Better identification of action priorities; } \\
\text { Integrated practices; } \\
\text { Evidence on increased expected losses due to } \\
\text { risk interactions; } \\
\text { Cost reduction and improvement in the efficiency of } \\
\text { mitigation measures. }\end{array}$ \\
\hline Institutional capacities & $\begin{array}{l}\text { Improved cooperation and coordination between agencies } \\
\text { acting at different levels in different risk sectors. }\end{array}$ \\
\hline Public private sector partnerships & $\begin{array}{l}\text { Enhanced cooperation and communication between public } \\
\text { and private sector; } \\
\text { Need for new responsibility sharing mechanisms in the case } \\
\text { of households exposed to multiple risks (insurance). }\end{array}$ \\
\hline
\end{tabular}

However, there are also some barriers to the adoption of a multi-risk approach, and in our research we first aimed at better understanding these barriers and identifying ways to overcome them (see Section 4.1). In order to do so, we conducted two empirical studies in communities exposed to multiple and inter-related risks in Italy and Guadeloupe, providing the necessary background to build a multi-risk governance framework (see Section 4.2).

\section{Research Design}

The research design aimed at collecting data and information on barriers to multi-risk governance and ways to overcome them. It included a wide array of methods and tools, such as interviews, questionnaire surveys, workshops and focus groups to encourage a two-way interaction between researchers and practitioners/decision-makers dealing with multi-risk issues. In total, ten researchers with different disciplinary backgrounds (ranging from geology to hydrology to social sciences) and more than seventy practitioners have been involved in the research undertaken within one workpackage (WP6) of the interdisciplinary EC funded project New Multi-Hazard and Multi-Risk Assessment Methods for Europe (MATRIX) (see Acknowledgments).

The involved practitioners included officers/directors of civil protection and fire brigades corps at different levels and for different risk sectors, researchers and university professors, and officers responsible for hazard/risk assessment, urban planning and emergency management, etc. from eleven different countries, namely Austria, Bulgaria, Croatia, France, Germany, Hungary, Iceland, Italy, Norway, Sweden and United Kingdom (for a detailed description of the research design, including a list of the participants, see [34,35]).

The research started with a policy/institutional analysis, i.e., desk studies of legal, regulatory and policy documents, which aimed at providing a description of the institutional and regulatory framework for risk governance within different natural hazard contexts and countries. To identify the barriers to multi-risk governance, we first performed interviews and focus group discussions with practitioners. In parallel, we performed multi-risk assessments considering some specific scenarios in the two test sites of Naples and Guadeloupe. 
Both Naples and Guadeloupe have embarked upon several short- and long-term plans and projects to make their citizens safer from multiple risks and have local experts in science, engineering and policy-making devoted to reducing risk and vulnerability. Also, in both test sites multi-risk assessment has been performed. In Naples, two scenarios of risk interactions were considered for quantitative analysis. On one hand, the effect (on seismic hazard and risk) of seismic swarms triggered by volcanic activity has been assessed, and on the other, the cumulative effect of volcanic ash and seismic loads has been analyzed. Both cases can be combined into a single scenario of interactions at the hazard and the vulnerability level, and highlight the different aspects of risk amplification detected by the multi-risk analysis [36].

In Guadeloupe, a scenario analysis of cascading effects and systemic risk has been conducted. This work has considered the interaction between earthquake and landslide phenomena and its consequences on the local road network in Guadeloupe and the transport of injured people to hospitals and clinics [37].

We presented the results during three workshops with practitioners (one in Napoli, one in Guadeloupe and one in Bonn), where we also discussed the barriers to and benefits of implementing multi-risk assessments. Finally, we submitted a questionnaire to the workshop participants to ask for their feedback. Table 2 summarizes the key research phases, the methods employed and the accompanying aims.

Table 2. Research phases [7].

\begin{tabular}{|c|c|c|}
\hline Research Phase & Methods & Aims \\
\hline $\begin{array}{c}\text { Institutional/policy } \\
\text { analysis }\end{array}$ & $\begin{array}{l}\text { Desk study of legal, regulatory, } \\
\text { and policy documents (Naples } \\
\text { and Guadeloupe). }\end{array}$ & $\begin{array}{l}\text { To provide a description of the institutional and } \\
\text { regulatory framework for risk governance within } \\
\text { different natural hazard contexts; } \\
\text { To identify comparable sets of governance } \\
\text { characteristics across hazards and countries. }\end{array}$ \\
\hline $\begin{array}{l}\text { Interviews and } \\
\text { focus groups }\end{array}$ & $\begin{array}{l}\text { Semi-structured and in-depth } \\
\text { interviews; focus group with a } \\
\text { total of } 44 \text { participants (Naples } \\
\text { and Guadeloupe). }\end{array}$ & $\begin{array}{l}\text { To identify the social and institutional barriers to } \\
\text { effective decision-making in the case of multiple } \\
\text { hazards; } \\
\text { To propose initial options for overcoming } \\
\text { multiple hazards; } \\
\text { To provide feedback on the results of the } \\
\text { institutional analysis. }\end{array}$ \\
\hline Workshops & $\begin{array}{l}\text { Three interdisciplinary workshops } \\
\text { with participants at national and } \\
\text { local levels from } 11 \text { countries; } \\
\text { Naples ( } 20 \text { participants); } \\
\text { Guadeloupe ( } 32 \text { participants); } \\
\text { Bonn ( } 21 \text { participants). }\end{array}$ & $\begin{array}{l}\text { To present the new multi-hazard and multi-risk } \\
\text { assessments and scenarios developed within the } \\
\text { MATRIX project; } \\
\text { To discuss the barriers to and benefits of } \\
\text { implementing multi-risk assessment in the test } \\
\text { sites and receive feedback from a wider audience } \\
\text { in order to identify results applicable to other } \\
\text { multi-risk environments. }\end{array}$ \\
\hline Feedback & $\begin{array}{l}\text { In-depth interviews with and } \\
\text { questionnaires submitted to } \\
\text { workshop participants (Naples } \\
\text { and Guadeloupe). }\end{array}$ & $\begin{array}{l}\text { To collect feedback on the workshops' results; } \\
\text { To collect feedback on the recommendations for } \\
\text { decision support developed by the research team } \\
\text { in the previous research phases. }\end{array}$ \\
\hline
\end{tabular}

The research has also benefited from the results and experience gained in other case studies and research projects, as discussed during the workshop in Bonn. Indeed, the practitioners and scientists involved in the project have reported upon lessons learnt, for example, from extreme cold and heat waves, earthquakes, flooding and windstorms in Cologne, Germany; floods and landslides in the lake Vanern district, Sweden; windstorms affecting the Blayais nuclear power plant in France; web-based decision support for multi-incident situations in Croatia, etc. In this paper we present some selected research results (for an overview of the research design and results see [34,35]). 


\section{Results}

\subsection{Institutional Barriers to Multi-Risk Governance}

The practitioners highlighted several barriers to the implementation of multi-risk governance and considered the institutional one as particularly difficult to overcome (for a summary of the other barriers, see also [34]).

First, a transformation of the present institutional frameworks is needed to really adopt a multi-risk perspective. This has to do with the past evolution of risk management and the interplay between scientific and institutional capacities. More precisely, the adoption of single-risk centered assessments implied also the endorsement of single-risk centered regulation, institutional frameworks, practices and decision-making processes. This means that at present: (i) domino effects are often not taken into account; (ii) priority identification is single-risk centered; (iii) hazards considered as major and primary (e.g., earthquakes) attract more resources than secondary induced effects (e.g., tsunamis); (iv) decisions are based on the risks that could be reduced the most and not necessarily on the highest assessed risks.

Second, the deep differences in the approaches, tools and methodologies used for single-risk assessment have resulted in a lack of integrated practices for multi-risk governance. The immediate consequence is that practitioners rarely have the opportunity to meet colleagues working in different risk fields and thus to discuss about cascading disasters. There are obviously exceptions with some countries adopting integrated risk management for landslides and floods (e.g., Italy and France). Yet, the results reveal that this hardly happens for multi-risk assessment focused on the domino effects between geological and hydrological hazards such as in the case of an earthquake causing a tsunami. The situation is different in the sector of emergency management where the approach is more holistic than in risk assessment. Emergency managers often already work with scenarios addressing multiple risks at the same time. Yet, other barriers are relevant in this phase of the disaster risk cycle.

Third, the interaction between public and private sectors, especially for what concerns chains-of-events between natural and industrial risks in emergency management is a critical barrier. Indeed, industrial emergency management is mostly under the responsibility of private actors (vs. natural risk which is instead under the responsibility of public authorities) but their work is often not integrated into the planning handled by public authorities. Another example is the role of private consultants in risk assessment. They often prepare or update risk assessment for local authorities and therefore collect and use huge amount of data. Implementing a culture of transparency for sharing data and results of different risk assessments is crucial to foster multi-risk assessment within the scope of multi-risk governance.

Fourth, responsibility for multi-risk reduction and mitigation at the household level is also critical. The structural and non-structural mitigation measures that a household can adopt change consistently, depending on the risk, on the country and on the availability of insurance schemes. Different levels of responsibility are attributed to property owners especially in geological versus meteo-hydrological risk prevention. For example in the case of earthquakes, the level of individual responsibility is high because property owners are usually in charge of household vulnerability reduction measures based on strict building codes (unless there are national funding covering it). In the case of floods, the decisions about risk mitigation measures such as protection works, depolderization of coastlines, etc., are under the responsibility of public authorities and costs are covered collectively. Securing buildings from floodwaters is often also a responsibility of the property owner (but most of the time the measures consist of water channels to better drain water and are less expensive than the measures required to secure against earthquake risk), and insurance schemes can be available-depending on the country. In general practitioners lament a lack of options for public-private responsibility sharing, especially in cases where households are exposed to multiple risks (and if insurance schemes are not available, as is the case in some European countries). 
Fifth, interagency cooperation and communication is also considered a barrier but cross-country differences matter. Cooperation is particularly difficult for risks that are managed by authorities acting at different levels (e.g., in Naples, the national level for volcanic risk and river basin area level for flood risk). For example, in Naples, the plan for volcanic emergency management has been prepared by the National Civil Protection, while hydro-geological emergency plans are under the responsibility of municipal authorities. Some practitioners also mention the lack of communication between emergency units and land-use planners (e.g., Sweden). However, there are exceptions: for example, practitioners from the UK mention that inter-agency cooperation works well.

Sixth, a last barrier is related to the lack of capacities, especially financial, but sometimes also technical and institutional at the local level. The same is not true for the responsibilities for disaster risk management that often fall on the shoulders of local authorities. It is well known that responsibilities for disaster risk reduction have often been transferred to the local level without sufficient resources to implement the programs. Among the key problematic issues, the practitioners mentioned the fact that mitigation funds are diverted to response. There are also difficulties to balance the budget between short-term needs and medium-term multi-risk mitigation. The lack of human resources is also sometimes an issue hindering the adoption of innovation in multi-risk management practice and governance. For example, the lack of time, of qualified or experienced personnel (in multi-risk), of leadership turnover (in some agencies) and the lack of resources for the transfer of competence and expertise (e.g., in Norway). Table 3 summarizes the key institutional barriers to the implementation of multi-risk governance.

Table 3. Institutional barriers to the implementation of multi-risk governance.

\begin{tabular}{|c|c|}
\hline Barrier & Description \\
\hline $\begin{array}{l}\text { Single risk centred } \\
\text { regulation and } \\
\text { institutional frameworks }\end{array}$ & $\begin{array}{l}\text { - Lack of integrated practices for risk management (that could support } \\
\text { the implementation of a multi-risk approach) } \\
\text { - Domino effects usually not included in risk zoning and urban planning }\end{array}$ \\
\hline $\begin{array}{l}\text { Different goals and } \\
\text { priorities of the agencies } \\
\text { in charge of hazard } \\
\text { management }\end{array}$ & $\begin{array}{l}\text { - Priority identification is single-risk centred and decisions are based on } \\
\text { the risks that could be most reduced and not necessarily the highest } \\
\text { assessed risks } \\
\text { Resources and capacities focused on hazards considered as major and } \\
\text { primary (e.g., earthquakes) with induced effects (e.g., tsunami) } \\
\text { being secondary }\end{array}$ \\
\hline $\begin{array}{l}\text { Unsatisfactory public } \\
\text { private partnership }\end{array}$ & $\begin{array}{l}\text { - Lack of communication between public and private actors (especially } \\
\text { between industrial and natural risk sector) } \\
\text { Private consultants at the forefront in case of contradictory results of } \\
\text { risk assessment }\end{array}$ \\
\hline $\begin{array}{l}\text { Different responsibilities } \\
\text { for risk reduction at } \\
\text { household level }\end{array}$ & $\begin{array}{l}\text { Lack of options for public-private responsibility sharing in case of } \\
\text { households exposed to multiple risks }\end{array}$ \\
\hline $\begin{array}{l}\text { Lack of interagency } \\
\text { communication }\end{array}$ & $\begin{array}{l}\text { - Cooperation and communication difficult for authorities acting at } \\
\text { different levels } \\
\text { - Lack of harmonisation of the practices and decision-making processes } \\
\text { across hazards }\end{array}$ \\
\hline $\begin{array}{l}\text { Lack of capacities at the } \\
\text { local level }\end{array}$ & $\begin{array}{ll}\text { - } & \text { Lack of financial, technical, etc. capacities at the local level } \\
\text { - } & \text { Mitigation funds diverted to response } \\
\text { - } & \text { Lack of human resources and time } \\
\text { - } & \text { Lack of qualified or experienced personnel (in multi-risk) } \\
\text { - } & \text { Leadership turnovers (in some agencies) }\end{array}$ \\
\hline
\end{tabular}




\subsection{Multi-Risk Governance Framework}

In this section, we build on the research results presented above and on the risk governance literature $[14,16,22]$ to present a multi-risk governance framework whose aim is to help decision-makers to take into account risk interdependencies. We define multi-risk governance as the various ways in which stakeholders manage multi-hazard and -risk issues related to cascading disasters. This includes decision-making processes related to all the phases of disaster risk reduction (from hazard-risk assessment to post-event recovery and reconstruction, including emergency planning, management, and risk mitigation). It is important to emphasize that the concept of multi-risk does not equate to a sum of governance practices for different single risks. Profiling the key characteristics of governance in diverse risk sectors is only one aspect of multi-risk governance (see also [38]). The investigation of cascades and associated effects is the crucial element of multi-risk governance. The framework (Figure 1) emphasise this aspect and foresees the following four phases:

- Observation of hazard and risk interactions, with a focus on the identification of cascades and associated effects;

- Analysis of the social and institutional context, including stakeholder engagement and the creation of forums/hubs to discuss, make decisions and set priorities for actions regarding multi-risk issues;

- Generation of multi-risk knowledge, including the use of different methods and tools (such as multi-risk assessment, hazard correlation matrix and risk migration matrix, etc.; e.g., [5,8,39] in order to provide a preliminary scientific background for the following phase of multi-risk knowledge co-production and decision-making;

- Stakeholder process, aimed at designing and selecting multi-risk management/reduction options; implementing the chosen options, and evaluating them.

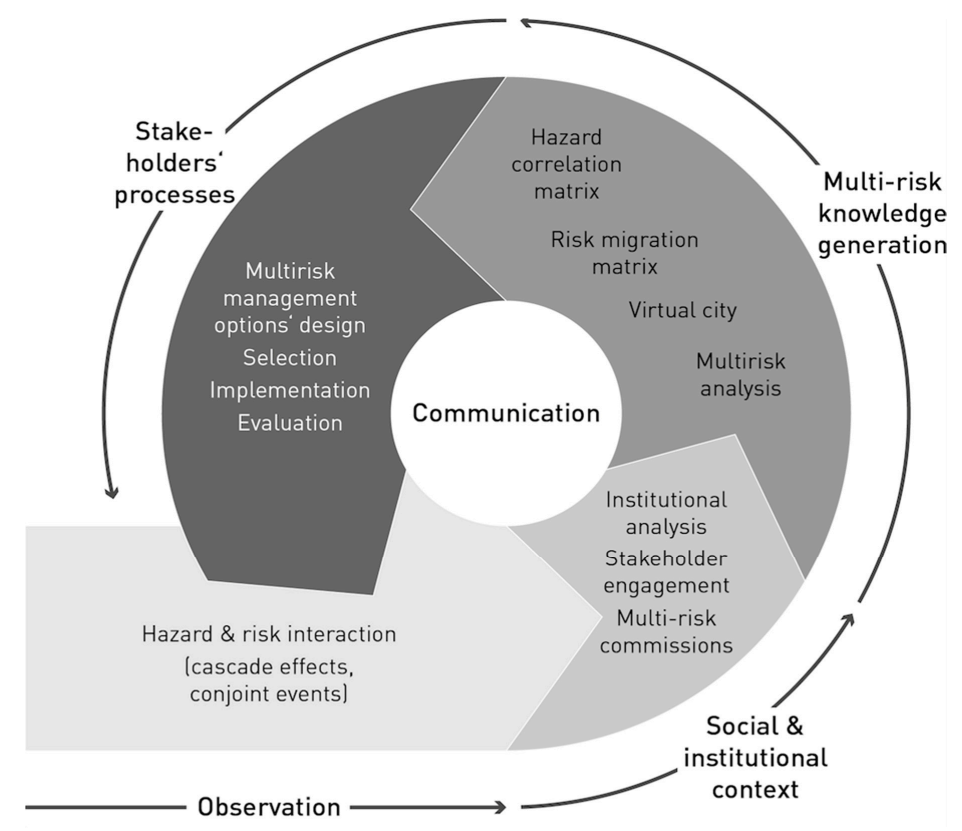

Figure 1. Multi-risk governance framework [14,16].

One of the key characteristics of this framework is that it addresses the functioning and interactions of physical and social systems and, as a consequence, it also accounts for the knowledge and expertise required to analyse them. Moreover science-policy communication is central: two-way communication and effective strategies to deal with scientific uncertainty are at the heart of effective multi-risk governance [40-47]. In the following sections we describe each single phase with a focus on the specific 
features of multi-risk governance and highlight some critical points that have to be addressed for future empirical testing and/or implementation.

\subsubsection{Phase 1: Observation of Hazard and Risk Interactions}

Multi-risk management involves the inclusion of hazard and risk interactions within the modelling of the disaster risk chain and the decision-making processes. These interactions can cause cascading effects and observation of these effects is a starting point to set a multi-risk governance framework. Multi-risk may be considered a wicked problem for several reasons, such as the high number of interdependencies between natural and socio-economic systems, the high number of stakeholders involved with different perspectives and priorities, and the limited policies and legislation addressing multi-risk issues $[5,23,48,49]$. Moreover, the high degree of uncertainty, the contested interests/values and the need for urgent action makes multi-risk governance a "classical" post-normal science problem [50,51].

It is important to emphasize here that today multi-risk assessment is already a standard procedure in some of the most critical infrastructure, such as nuclear power plants, where complex chains of events are considered in stress tests (see also industrial risk assessment methods; e.g., [52]. However, cascades are often only considered between functional elements (with the particular type of infrastructure as the focus of analysis) and not between natural hazards or between natural and technological hazards, as in the case of the 2011 Fukushima disaster [53]. Therefore, a reflection on possible risk interactions is the necessary next step, as also shown by several other studies [54-56]. Also, the relationships between public and private actors need to be taken into account and both sectors have to be involved in the stakeholder process (see phase 4). Another necessary step before performing the actual multi-risk assessment is the identification of the most dangerous multi-risk environment at the local, national or, even more difficult, global level (see also phase 3 of multi-risk knowledge generation).

\subsubsection{Phase 2: Social and Institutional Context Analysis}

An analysis of the social and institutional context starts with a descriptive phase to provide an overview of the agencies dealing with single risk management at different levels. The aim of this analysis is to map the key stakeholders, including their tasks and responsibilities, what they think and already know about domino effects, how these effects are included into urban planning, etc. After this descriptive analysis, a better understanding of the perspectives, interests, needs, level of influence on decision-making processes and expectations of different stakeholders from the public and private sector can be performed by means of semi-structured interviews and focus groups targeting topics such as cascading effects, other risk interactions, and "worst case" scenarios, among other issues. This means taking into account stakeholder opinions, interests, and needs before even starting a decision-making process about multi-risk issues. This qualitative analysis also helps to identify the possible conflicts among stakeholders that may emerge when dealing with multiple risks. Evidence already shows that an early analysis of these conflicts can improve the overall quality of decision-making and avoid stalemates [57].

The possibility for conflicts in multi-risk governance exists in inter-agency cooperation and coordination, especially for responsibility allocation in cases where different agencies are responsible for different risks. For example, in many European countries the plans for volcanic risk assessment are prepared at the national level, and for hydro-geological risk at the river basin level. Earthquake risk assessment is under the responsibility of regional or municipal authorities, while in the case of technological risks private actors are in the front line [38].

Considering these different levels of governance involved, the question is clear: Who should take responsibility for multi-risk governance and at what institutional level?

In order to effectively respond to environmental problems and risks, it has repeatedly been proposed that the scale of governance institutions should be adapted to that of the environmental issues [58]. For instance, the EU Water Framework Directive (2000/60/EC) mandates river basins as 
the relevant units for planning, water management, flood and landslide risk assessment, etc. However, what happens in the case of multi-risk governance? What is the scale of the environmental issue at stake? Should new authorities, commissions or policy forums be created?

At present, these issues are still open because they are highly dependent upon contextual factors. The relationship between authorities at the local and national levels and especially the role of national authorities are critical aspects. Indeed it may be easier to introduce the multi-risk approach to governance institutions at the local level than at the national level. This is mainly due to the fact that scientific knowledge on multi-risk assessment is patchy and scenarios are often context- and site-specific. Previous research results suggest that the creation of local multi-risk commissions (i.e., institutional arenas to discuss and take action on multi-risk issues with an interdisciplinary and multi sector character) is a good option for multi-risk governance [5,7]. Members of these commissions should include experts with experience in multi-risk assessment and backgrounds in different risk areas (meteorological, geological, technological, etc.), along with practitioners, representatives of Non-Governmental Organisations or associations dealing with environmental issues or emergency management, and local natural hazard advisors. The latter can act as the liaising bodies between local communities and practitioners (Commissions including local natural hazard advisors have already been created in some countries, e.g., Switzerland, but they do not have a multi-risk dimension). The advisors should be trained to be able to combine the multi-risk information provided by practitioners and experts with their own on-site observations and local experience. They can be volunteers, (e.g., the equivalent of voluntary fire brigades) but with skills in risk issues, rather than emergency management. The main aims of these commissions should be to: (i) better understand stakeholders perspectives; (ii) provide suggestions for the inclusion of multi-risk assessment, scenarios, etc. (see also phase 3 on the generation of multi-risk knowledge) in urban planning; (iii) develop educational and training activities; (iv) discuss responsibility sharing between private and public actors for developing new multi-risk financing schemes, in case of households exposed to multiple risks, for example.

Because of the mix of their members, these commissions would represent a boundary organisation to bridge the gap between research and policy [47]. Similar organisations, especially in the climate adaptation sector, already exist. The New York City Climate Change Program, for example, is aimed at coordinating interdisciplinary research focused on New York climate risk and helping decision-makers integrate climate change adaptation into urban decisions [59]. More generally, integrated approaches to climate adaptation often highlight the need to engage experts and decision-makers in an iterative exchange of information on the multiple risks related to climate change. These commissions may bring stability to the relationship between science and policy-makers by providing platforms and forums for exchange and discussion.

Further empirical research is needed in order to examine the role these commissions should play at the local level. At the same time mainstreaming multi-risk issues in the present risk (and climate) policy cycles at the national level is a further challenge.

\subsubsection{Phase 3: Multi-Risk Knowledge Generation}

Existing multi-risk methods may be considered applied science (i.e., proofs-of-concept of multi-risk applicability to specific sites) and professional consultancy (e.g., stress tests) [50]. So far, due to the overwhelming complexity of natural and socioeconomic systems, multi-risk scenarios have been mostly limited to one or two specific interactions at a given site. For instance, cascade failures across water and electricity networks due to an earthquake in Memphis, USA [60] or an industrial accident triggered by volcanic ash load at Casalnuovo, Italy [13]. Attempts at a comprehensive treatment of multi-risk approaches remain at the generic level $[8,61]$.

New tools to improve the scientific foundations of multi-risk assessment, accounting for issues such as complexity, uncertainties, and low-probability-high-consequence events, are in development. Initial steps in this direction include the development of the hazard correlation and risk migration 
matrices for the development, analysis, and selection of quantitative multi-risk scenarios [8]. Moreover, the development of a virtual city for example, can be a useful tool to simulate multi-risk urban scenarios and help practitioners understand the decision-making processes surrounding interrelated risks $[5,62,63]$.

First, the hazard correlation matrix (HCM) is a tool for developing multi-risk scenarios. It is a square matrix in which rows represent trigger events and columns target events. Each cell represents the expected interaction between two given events, described qualitatively (triggering, inhibiting, no link) or quantitatively (conditional probability of occurrence). While roughly similar in structure to existing hazard matrices, the HCM was built to include any type of hazard and interaction in order to quantify the complexity of the natural and socio-economic systems. The HCM method was recently given a preliminary test by high school teachers in natural sciences. The results demonstrated the effectiveness of the HCM as a tool for transformative learning as it facilitated the understanding of complex chains of events by the analysis of simple one-to-one interactions [64]. The method has yet to be formerly tested but it could be very helpful for practitioners such as critical infrastructure operators, for instance, who need to evaluate the impact of possible cascade effects in stress tests. It could also be used as a type of working document during multi-risk commission sessions. The HCM is the main input to the generic multi-risk (GenMR) framework, which analyses those interactions [8].

Second, the risk migration matrix (RMM) is a tool for the selection of multi-risk scenarios. It is based on the concept of a risk matrix, which is often used by practitioners, and is complementary to the loss curve, which is mostly used by insurance companies ([5] and references therein). In contrast to the standard risk matrix where experts rank different risk scenarios by loss and frequency ranges, the RMM shows the difference between two risk matrices that represent two different hypotheses. In general, these hypotheses would be multiple single risk scenarios versus multi-risk scenarios. This approach allows its user to better understand and evaluate the added value of multi-risk analysis. While the original risk matrix is semi-quantitative, the RMM is quantitative and is one of the main outputs of the GenMR framework $[8,62]$.

Third, the concept of a virtual city $[5,62,63]$ can be defined as a template for simplified multi-risk analyses where generic data and interaction processes are predefined. It allows a better understanding of complex multi-risk processes by by-passing the cumbersome data models and algorithm black boxes and focusing on the main aspects of the multi-risk approach. Being a virtual environment, any multi-risk scenario can be explored by using, for instance, reasoned imagination (e.g., [65], which is an important concept for dealing with complexity and high uncertainties.

To bridge knowledge generation and stakeholder processes, Liu and colleagues [63] propose a multi-level, multi-risk approach that complements the tools presented in this section and proposes a roadmap to understand if and when a multi-risk approach is necessary. Their first level is a flow chart that guides the user in deciding whether a multi-hazard and -risk approach is required. The second level is a semi-quantitative approach to explore if a more detailed, quantitative assessment is needed. The third and final level is a detailed quantitative multi-risk analysis. This approach can form the basis to discuss different options to best manage multi-risk issues.

\subsubsection{Phase 4: Stakeholder Process}

The stakeholder process starts by reviewing all relevant data, information, and results generated during the previous steps. At this stage the framework envisions that the commissions/forums have been set up and that preliminary multi-risk knowledge has been generated. The commissions are indeed the institutional arenas where the stakeholder process and expert-stakeholder knowledge co-production takes place.

The central activity of this phase is the design of multi-risk management options that take into account both stakeholders' perspectives (analyzed in Phase 2 [49]) and experts' technical knowledge (produced in Phase 3). Its core feature is the interactive coupling of expert-formulated technical options with values and worldviews expressed by the local stakeholders. In this way, constructive account is 
taken of both the specialist expert knowledge and the local (and more generalized) lay knowledge and values (see also [15]).

The options should be focused on potential domino effects, interactions among risks and hazards, and on the identification of consequences of extreme events. Depending on the case study and the knowledge already available, the options can be qualitative, quantitative or a mix of both.

Two aspects should be emphasized within the option identification and selection process. First, the institutional analysis and preliminary stakeholder engagement (especially in Phase 2) should provide relevant information to allow identification of different views and perspectives on how to reduce risks with a multi-risk approach. These views are crucial to generate multi-risk reduction options. Stakeholders may have very divergent views on priorities for multi-risk reduction, for example, reinforce existing buildings, improve earthquake early warning systems, reinforce active measures to mitigate landslide risk, improve relocation and emergency plans etc. Each option has different costs, reduces risks to a different extent, could be improved by using different kinds of expertise, and requires different time periods to be implemented.

Second, in this phase the role of experts is to provide different options that reflect the social perspectives analyzed in Phase 2, and the technical knowledge produced in Phase 3. This process balances social views with technical evidence, uncertainties, and institutional, legal and social contextual factors [15]. Experts in multi-risk issues should not provide one solution but rather cooperate with stakeholders in order to translate and transform their qualitative views and discourses into technical options [51,66-70]. Rather than being advocates of one solution, experts should explain the different options and related trade-offs.

After the discussion of the options, the debate should focus on finding a compromise solution. Evaluation is also a critical step that should focus on both outcome and process. Political actions and decisions should also be evaluated to guide future multi-risk approaches. Stakeholder-driven evaluation is of key importance here [24], and "fit for purpose" criteria should be defined in order to evaluate the quality and efficacy of multi-risk decisions. The work of the multi-risk commissions does not end with the compromise solution and the evaluation of the stakeholder process. The commissions should meet regularly and continue the discussion on multi-risk issues, based on the new knowledge available and decisions about risk reduction measures implementation. In this way, the cycle described in Figure 1 will start again. Ideally prevention measures will be implemented after each cycle is completed. However several other barriers, typically financial ones, may hinder of delate these process.

\section{Conclusions}

While new theories and methods for multi-risk assessment have been developed in the past decade, the same is not true for theories and methods of multi-risk governance. If it is clear that the new multi-risk science can considerably improve planning and emergency management, it is still not yet clear how it can drive governance innovation in risk decision-making, legislation and policy. A science-policy divide is apparent and needs to be addressed to mainstream multi-risk approaches in national and local risk policies.

While single risk governance has been discussed in several publications, multi-risk governance is a new concept not yet operational for policy and management. To our knowledge, a review of multi-risk policies enacted at national or local level and of their implementation is still not yet available and very few studies have been conducted to compare and contrast different experiences.

The analysis of institutional barriers presented in this paper shows that mainstreaming multi-risk issues in the present national risk policy cycles is particularly difficult. One option to do so could be to promote comprehensive surveys on multi-hazard disaster risk and promote a better national coordination of methodologies, procedures and practices enacted at the local level. Moreover since multi-risk and global change issues are comparable by their intrinsic complexity, the development of multi-risk governance should also take into account the pros and cons of existing climate change and adaptation risk governance schemes. 
As opposed to single risk, multi-risk governance demands a higher degree of cooperation between the public and private sector in order to understand and better manage unexpected events and their consequences (especially in the case of interactions between natural and industrial risks). At the same time, a multi-risk approach has the potential to lead to significant cost reductions, improvements in the efficiency of risk mitigation and management measures, better identification of action priorities and reduction of multi-risk losses. Taking these benefits into account, several multi-risk governance frameworks can be imagined. Here we propose a framework which includes the phases of multi-risk environment observation, social and institutional context analysis, co-design of risk reduction options between experts and stakeholders involved in multi-risk commissions, and implementation.

The co-production of knowledge between experts and local stakeholders is a key characteristic of this framework. What differentiates it from other governance frameworks is the fact that experts play a unique role by providing a range of multi-risk management options that correspond to the different stakeholders' perspectives. Experts help co-produce usable knowledge for policy processes as well as providing informed opinions and balancing evidence, uncertainties, economic, institutional and social contextual factors.

The framework has also a number of limitations. For example it is still not clear if multi-risk commissions acting as boundary organisations would improve inter-agency cooperation, communication, or create opportunities for collaboration at the local level. The risk is that these commissions may actually increase institutional complexity and generate decisional stalemates. Their introduction may therefore result in the opening up of science to political influence, which may in its own turn jeopardise the whole process, especially if experts are not ready to reinterpret their role in the framework, i.e., changing from advocates of one solution to brokers of different options.

We hope that this framework will provide inputs to develop a more comprehensive and systematic approach to multi-risk governance. This work shall also encourage the much-needed communication between the natural and social science communities and between scientists and practitioners working in multi-risk environments. Yet, more empirical testing and evidence is needed in order to verify these assumptions and identify the hallmarks of good multi-risk governance models.

Acknowledgments: In this paper we grounded on the results of a project supported by the European Community's Seventh Framework Programme through the grant to the budget of the MATRIX project-new methodologies for multi-hazard and multi-risk assessment methods for Europe [FP7/20112013] under grant agreement $n^{\circ} 265138$. The paper reflects the authors' views and not those of the European Community. Neither the European Community nor any member of the Matrix Consortium is liable for any use of the information in this paper. We wish to thank all the colleagues and persons who provided us with professional advice and collaboration during the MATRIX project. We also thank Sandro Bosch, ETH Zurich, for support in grafic design.

Author Contributions: All authors conceived and designed the paper together. Anna Scolobig wrote the paper, with original contributions of Nadya Komendantova and Arnaud Mignan to all the paper sections.

Conflicts of Interest: The authors declare no conflict of interests.

\section{Appendix (Selected) Risk Governance Definitions and Features}

Table A1. (Selected) risk governance definitions and features.

\begin{tabular}{clll}
\hline Study & \multicolumn{1}{c}{ Problem Definition } & Definition of Risk Governance & \multicolumn{1}{c}{ Major Features } \\
\hline & $\begin{array}{l}\text { There is a need to better } \\
\text { accommodate conflicting or } \\
\text { diverse interests and take } \\
\text { co-operative actions in } \\
\text { policy making. }\end{array}$ & $\begin{array}{l}\text { The sum of the many ways } \\
\text { individuals and institutions, } \\
\text { public and private, manage their } \\
\text { common affairs. }\end{array}$ & $\begin{array}{l}\text { It includes formal institutions } \\
\text { and regimes empowered to } \\
\text { enforce compliance, as well as } \\
\text { informal arrangements that } \\
\text { people and institutions either } \\
\text { have agreed to or perceive to be } \\
\text { in their interest. }\end{array}$ \\
\hline
\end{tabular}


Table A1. Cont.

\begin{tabular}{|c|c|c|c|}
\hline Study & Problem Definition & Definition of Risk Governance & Major Features \\
\hline [21] & $\begin{array}{l}\text { Contemporary risk crises } \\
\text { show the need to incorporate } \\
\text { societal concerns as well as } \\
\text { non standard knowledge in } \\
\text { the governance of risk. } \\
\text { These crises cannot be fully } \\
\text { understood nor managed with } \\
\text { traditional risk } \\
\text { assessment tools. }\end{array}$ & $\begin{array}{l}\text { The sum of the many ways } \\
\text { individuals and institutions, } \\
\text { public and private, manage their } \\
\text { common affairs. It is often related } \\
\text { to the precautionary principle, } \\
\text { combining the idea of 'sound } \\
\text { science' with public participation. }\end{array}$ & $\begin{array}{l}\text { The full realisation of } \\
\text { governance enquires a shift of } \\
\text { mentality, broad changes in } \\
\text { professional and institutional } \\
\text { practices, and the design and } \\
\text { implementation of new } \\
\text { participatory instruments and } \\
\text { procedures. }\end{array}$ \\
\hline [48] & $\begin{array}{l}\text { Policy problems such as } \\
\text { handling conflict in } \\
\text { environmental, transport, } \\
\text { ageing and health policy are } \\
\text { becoming increasingly messy } \\
\text { and new governance } \\
\text { approaches are needed to } \\
\text { identify clumsy solutions. }\end{array}$ & $\begin{array}{l}\text { Effective governance approaches } \\
\text { allow to identify clumsy solutions, } \\
\text { i.e., creative combinations of four } \\
\text { opposing ways of organizing and } \\
\text { thinking. }\end{array}$ & $\begin{array}{l}\text { Clumsy governance solutions } \\
\text { emerge from compromises } \\
\text { among the four forms of social } \\
\text { solidarity: individualism, } \\
\text { hierarchy, fatalism and } \\
\text { egualitarianism. }\end{array}$ \\
\hline [18] & $\begin{array}{l}\text { Risk governance framework is } \\
\text { needed to address complexity } \\
\text { in identification and } \\
\text { quantification of causal links, } \\
\text { uncertain assumptions, } \\
\text { assertions and predictions as } \\
\text { well as interpretative and } \\
\text { normative ambiguity of } \\
\text { justifications for } \\
\text { different threats. }\end{array}$ & $\begin{array}{l}\text { It is a systematic approach to } \\
\text { decision and policy-making } \\
\text { processes on natural and } \\
\text { technological risks based on } \\
\text { principles of cooperation, } \\
\text { participation and effective risk } \\
\text { management in public and } \\
\text { private policies. }\end{array}$ & $\begin{array}{l}\text { Evaluation of risk management } \\
\text { options should be done in } \\
\text { cooperation between experts } \\
\text { and decision-makers, where } \\
\text { evidence comes from experts } \\
\text { and relative weights on decision } \\
\text { criteria from politically } \\
\text { legitimised decision-makers. } \\
\text { Risk communication should } \\
\text { deal with the nature of risks, } \\
\text { their context and source as well } \\
\text { as societal concerns. }\end{array}$ \\
\hline [22] & $\begin{array}{l}\text { Risk governance is needed as } \\
\text { an essential element to } \\
\text { guarantee an integrated } \\
\text { approach for natural } \\
\text { risk reduction. }\end{array}$ & $\begin{array}{l}\text { It refers to actions, processes, } \\
\text { traditions, networks and } \\
\text { institutions by which decisions are } \\
\text { taken and implemented. }\end{array}$ & $\begin{array}{l}\text { It includes the phases of } \\
\text { pre-assessment, risk appraisal } \\
\text { (tolerability, acceptability, } \\
\text { judgement), risk evaluation, } \\
\text { risk management } \\
\text { and communication. }\end{array}$ \\
\hline [71] & $\begin{array}{l}\text { Limited understanding of } \\
\text { processes which lead to } \\
\text { improvement or deterioration } \\
\text { of natural resources because of } \\
\text { use of different languages and } \\
\text { concepts to describe complex } \\
\text { social-ecological systems. }\end{array}$ & $\begin{array}{l}\text { It is a framework to organise } \\
\text { findings and knowledge } \\
\text { generated by different disciplines } \\
\text { and stakeholders. Governance } \\
\text { systems are understood as } \\
\text { organizations and rules that } \\
\text { govern social-ecological systems } \\
\text { and interactions with subsystems } \\
\text { and their components. }\end{array}$ & $\begin{array}{l}\text { Focus on relationship among } \\
\text { multiple levels of complex } \\
\text { systems at different spatial and } \\
\text { temporal scales. Bottom-up } \\
\text { approach by involving expertise } \\
\text { of stakeholders. }\end{array}$ \\
\hline [72] & $\begin{array}{l}\text { Limitation of traditional } \\
\text { analytical models and } \\
\text { methodological tools to } \\
\text { understand complex } \\
\text { perspective on issues of } \\
\text { environmental change. }\end{array}$ & $\begin{array}{l}\text { Resilience and governance as } \\
\text { fundamental issues of change and } \\
\text { stability, adaptation and design, } \\
\text { hierarchy and self-organization in } \\
\text { multilevel governance systems. } \\
\text { This includes also such elements } \\
\text { as human-environmental } \\
\text { interactions, vulnerability } \\
\text { resulting from mal-adaptations } \\
\text { and innovation capacity as } \\
\text { integral parts of a given } \\
\text { governance system. }\end{array}$ & $\begin{array}{l}\text { To govern processes of complex } \\
\text { change, complexity in the } \\
\text { external world shall be matched } \\
\text { by complexity in governance } \\
\text { systems. Institutional and } \\
\text { organisational diversity is the } \\
\text { most effective way to cope } \\
\text { with complexity. }\end{array}$ \\
\hline
\end{tabular}


Table A1. Cont.

\begin{tabular}{clll}
\hline Study & \multicolumn{1}{c}{ Problem Definition } & Definition of Risk Governance & \multicolumn{1}{c}{ Major Features } \\
\hline [73] & $\begin{array}{l}\text { The need of current } \\
\text { frameworks to address } \\
\text { multiple risks. }\end{array}$ & $\begin{array}{l}\text { Governance includes capacities of } \\
\text { systems at different levels, from } \\
\text { local to global, to deal with } \\
\text { several risks. It entails risk policy } \\
\text { and politics. }\end{array}$ & $\begin{array}{l}\text { Governance structures at } \\
\text { different levels. }\end{array}$ \\
\hline & $\begin{array}{l}\text { Reduction of cumulative } \\
\text { impact on ecosystems, which } \\
\text { requires co-evolution between } \\
\text { science, policy and practice. } \\
\text { Major pillars: long-term } \\
\text { social-ecological changes, } \\
\text { resilience of ecosystems, } \\
\text { driving forces and points } \\
\text { of challenges. }\end{array}$ & $\begin{array}{l}\text { Multi-level governance is needed } \\
\text { to adequately support operational } \\
\text { application of ecosystem } \\
\text { approach. Experimentation and } \\
\text { innovation at local and regional } \\
\text { levels as well as establishing } \\
\text { science-based learning platforms } \\
\text { are key pre-requisites. }\end{array}$ & $\begin{array}{l}\text { Movement towards a new } \\
\text { governance regime, combining } \\
\text { bottom-up pilot initiatives for } \\
\text { diffusion of innovation within } \\
\text { the existing governance } \\
\text { framework and top-down } \\
\text { approach, which enables EU } \\
\text { legislation to } \\
\text { stimulate innovations. }\end{array}$ \\
\hline \multirow{2}{*}{$\begin{array}{l}\text { Complexity, uncertainty and } \\
\text { socio-political ambiguity are } \\
\text { three key challenges that } \\
\text { governance should address. }\end{array}$} & $\begin{array}{l}\text { Risk governance denotes both the } \\
\text { institutional structure and the } \\
\text { policy process that guide and } \\
\text { restrain collective activities of a } \\
\text { group-society to regulate, reduce } \\
\text { or control risk problems. }\end{array}$ & $\begin{array}{l}\text { It includes steps of } \\
\text { pre-estimation, interdisciplinary } \\
\text { risk estimation, risk } \\
\text { characterisation and evaluation, } \\
\text { risk management, monitoring } \\
\text { and control. }\end{array}$ \\
\hline
\end{tabular}

Note: the literature is reported in chronological order. We report only one example of publication per each author/group of authors/institutions even if we are completely aware that each one of them has many other publications on the topic of risk governance.

\section{References}

1. The Sendai Framework for Disaster Risk Reduction 2015-2030. Available online: http:/ /www.unisdr.org/ files/43291_sendaiframeworkfordrren.pdf (accessed on 9 December 2017).

2. Komendantova, N.; van Erp, N.; van Gelder, P.; Patt, A. Individual Perceptual and Cognitive Barriers to Multi-Hazard Management; MATRIX: Laxenburg, Austria, 2013.

3. Mitchell, J. Megacities and natural disasters: A comparative analysis. GeoJournal 1999, 49, 137-142. [CrossRef]

4. The official Report of the Fukushima Nuclear Accident Independent Investigation Commission; The National Diet of Japan: Tokyo, Japan, 2012.

5. Mignan, A.; Komendantova, N.; Scolobig, A.; Fleming, K. Multi-risk assessment and governance. In Handbook of Disaster Risk Reduction and Management; Madu, C.N., Kuei, C.H., Eds.; World Sci. Press \& Imperial College Press: London, UK, 2017; Chapter 14, pp. 357-381. [CrossRef]

6. Komendantova, N.; Scolobig, A.; Garcia-Aristizabal, A.; Monfort, D.; Fleming, K. Multi-risk approach and urban resilience. Int. J. Disaster Resil. Built Environ. 2016, 7, 114-132. [CrossRef]

7. Scolobig, A.; Garcia-Aristizabal, A.; Komendantova, N.; Patt, A.; Di Ruocco, A.; Gasparini, P.; Monfort, D.; Vinchon, C.; Bengoubou-Valerius, M.; Mrzyglocki, R.; et al. From multi-risk assessment to multi-risk governance: Reccomendations for future directions. In Understanding Risk: The Evolution of Disaster Risk Assessment Since 2015; World Bank: Washington, DC, USA, 2014; pp. 163-167.

8. Mignan, A.; Wiemer, S.; Giardini, D. The quantification of low-probability-high-consequences events: Part I. A generic multi-risk approach. Nat. Hazards 2014, 73, 1999-2022. [CrossRef]

9. Kappes, M.; Keiler, M.; von Elverfeldt, K.; Glade, T. Challenges of analyzing multi-hazard risk: A review. Nat. Hazards 2012, 64, 1925-1958. [CrossRef]

10. Kappes, M.S.; Gruber, K.; Frigerio, S.; Bell, R.; Keiler, M.; Glade, T. The multirisk platform: The technical concept and application of a regional-scale multihazard exposure analysis tool. Geomorphology 2012, 151-152, 139-155. [CrossRef]

11. Gallina, V.; Torresan, S.; Critto, A.; Sperotto, A.; Glade, T.; Marcomini, A. A review of multi-risk methodologies for natural hazards: Consequences and challenges for a climate change impact assessment. J. Environ. Manag. 2016, 168, 123-132. [CrossRef] [PubMed] 
12. Sperotto, A.; Molina, J.L.; Torresan, S.; Critto, A.; Marcomini, A. Reviewing bayesian networks potentials for climate change impacts assessment and management: A multi-risk perspective. J. Environ. Manag. 2017, 202, 320-331. [CrossRef] [PubMed]

13. Marzocchi, W.; Garcia-Aristizabal, A.; Giardini, P.; Mastellone, M.; Di Ruocco, A. Basic principles of multi-risk assessment: A case study in Italy. Nat. Hazards 2012, 62, 551-573. [CrossRef]

14. Klinke, A.; Renn, O. Adaptive and integrative governance on risk and uncertainty. J. Risk Res. 2011, 15, 273-292. [CrossRef]

15. Linnerooth-Bayer, J.; Scolobig, A.; Ferlisi, S.; Cascini, L.; Thompson, M. Expert engagement in participatory processes: Translating stakeholder discourses into policy options. Nat. Hazards 2016, 81, 69-88. [CrossRef]

16. Renn, O.; Klinke, A. Risk governance and resilience: New approaches to cope with uncertainty and ambiguity. In Risk Governance: The Articulation of Hazard, Politics and Ecology; Paleo, U.F., Ed.; Springer: Berlin, Germany, 2015; pp. 19-41.

17. Hyogo framework for action 2005-2015: Building the resilience of nations and communities to disasters. In The Final Report of the World Conference on Disaster Reduction; A/CONF. 206/6; UNISDR: Kobe, Japan, 2005; pp. 18-22.

18. Renn, O. Risk Governance. Coping with Uncertainty in a Complex World, 1st ed.; Earthscan: London, UK, 2008.

19. Our Global Neighborhood; Commission on Global Governance: London, UK, 1995.

20. De Marchi, B. Risk governance and the integration of scientific and local knowledge. In Risk Governance: The Articulation of Hazard, Politics and Ecology; Paleo, U.F., Ed.; Springer: Berlin, Germany, 2015; pp. $19-41$.

21. De Marchi, B. Public participation and risk governance. Sci. Public Policy 2003, 30, 171-176. [CrossRef]

22. International Risk Governance Council (IRGC). An Introduction to the Risk Governance Framework; International Risk Governance Council: Geneva, Switzerland, 2008.

23. Thompson, M. Organizing and Disorganizing: A Dynamic and Non-Linear Theory of Institutional Emergence and Its Implications, 1st ed.; Triarchy Press: London, UK, 2008.

24. Paleo, U.F. Risk Governance: The Articulation of Hazard, Politics and Ecology, 1st ed.; Springer: Berlin, Germany, 2015.

25. Thompson, M.; Rayner, S. Risk and governance part 1: The discourses of climate change. Gov. Oppos. 1998, 33, 139-166. [CrossRef]

26. Bevir, M. Key Concepts in Governance, 1st ed.; SAGE Books: London, UK, 2009.

27. Biermann, F. Earth system governance as a crosscutting theme of global change research. Glob. Environ. Chang. 2007, 17, 326-337. [CrossRef]

28. Newig, J.; Fritsch, O. Environmental governance: Participatory, multi-level and effective? Environ. Policy Gov. 2009, 19, 197-214. [CrossRef]

29. Ikeda, S.; Nagasaka, T. An emergent framework of disaster risk governance towards innovating coping capability for reducing disaster risks in local communities. Int. J. Disaster Risk Sci. 2011, 2, 1-9. [CrossRef]

30. Biesbroek, G.R.; Termeer, C.A.M.; Klostermann, J.M.; Kabat, P. Analytical lenses on barriers in the governance of climate change adaptation. Mitig. Adapt. Strateg. Glob. Chang. 2013, 19, 1-22. [CrossRef]

31. Concept Note: Improving the Management of Emerging Risks: Risks from New Technologies, System Interactions, and Unforeseen or Changing Circumstances; International Risk Governance Council (IRGC): Geneva, Switzerland, 2011.

32. Kaufmann, D. Governance Matters; World Bank: Washington, DC, USA, 1999.

33. Bakkour, D.; Enjolras, G.; Thouret, J.C.; Kast, R.; Mei, E.T.W.; Prihatminingtyas, B. The adaptive governance of natural disaster systems: Insights from the 2010 mount merapi eruption in indonesia. Int. J. Disaster Risk Reduct. 2015, 13, 167-188. [CrossRef]

34. Scolobig, A.; Komendantova, N.; Patt, A.; Vinchon, C.; Monfort, D.; Bengoubou-Valerius, M.; Gasparini, P.; Di Ruocco, A.; Garcia-Aristizabal, A.; Wenzel, F. Synthesis: Benefits and Barriers to Multi-Hazard Mitigation and Adaptation, with Policy Recommendations for Decision-Support; MATRIX: Laxenburg, Austria, 2013.

35. Scolobig, A.; Vinchon, C.; Komendantova, N.; Bengoubou-Valerius, M.; Patt, A.; Gasparini, P.; Di Ruocco, A.; Baills, A.; Revellière, A. Social and Institutional Barriers to Effective Multi-Hazard Decision Making; MATRIX: Laxenburg, Austria, 2013.

36. Garcia-Aristizabal, A.; Marzocchi, W.; Di Ruocco, A.; Tyagunov, S.; Vorogushyn, S.; Fleming, K.; Desramaut, N. Scenarios of Cascade Events; MATRIX: Laxenburg, Austria, 2013.

37. Monfort, D.; Lecacheux, S.; French, S. West Indies Test Site; MATRIX: Laxenburg, Austria, 2013. 
38. Scolobig, A.; Komendantova, N.; Patt, A.; Vinchon, C.; Monfort-Climent, D.; Begoubou-Valerius, M.; Gasparini, P.; Di Ruocco, A. Multi-risk governance for natural hazards in naples and guadeloupe. Nat. Hazards 2014, 73, 1523-1545. [CrossRef]

39. Mignan, A.; Danciu, L.; Giardini, D. Considering Large Earthquake Clustering in Seismic Risk Analysis. Nat. Hazards 2016, 1-24. [CrossRef]

40. Patt, A.G.; Weber, E.U. Perceptions and communication strategies for the many uncertainties relevant for climate policy. WIREs Clim. Chang. 2014, 5, 219-232. [CrossRef]

41. Fischhoff, B. Risk perception and communication unplugged: Twenty years of process. Risk Anal. 1995, 15, 137-145. [CrossRef] [PubMed]

42. Fischhoff, B. The sciences of science communication. In Proceedings of the National Academy of Sciences, Washington, DC, USA, 21-22 May 2012; pp. 14033-14039.

43. Otway, H.; Wynne, B. Risk communication: Paradigm and paradox. Risk Anal. 1989, 9, 141-145. [CrossRef]

44. Kasperson, R. Four questions for risk communication. J. Risk Res. 2014, 17, 1233-1239. [CrossRef]

45. Siegrist, M. More questions than answers: A response to "four questions for risk communication" by Roger Kasperson (2014). J. Risk Res. 2014, 17, 1241-1243. [CrossRef]

46. De Marchi, B. Uncertainty in environmental emergencies: A diagnostic tool. J. Conting. Crisis Manag. 1995, 3, 103-112. [CrossRef]

47. Cash, D.W.; Clark, W.C.; Alcock, F.; Dickson, N.M.; Eckley, N.; Guston, D.H.; Jäger, J.; Mitchell, R.B. Knowledge systems for sustainable development. Proc. Natl. Acad. Sci. USA 2003, 100, 8086-8091. [CrossRef] [PubMed]

48. Verweij, M.; Thompson, M. Clumsy Solutions for A Complex World: Governance, Politics, and Plural Perceptions, 1st ed.; Palgrave Macmillan: New York, NY, USA, 2006.

49. Thompson, M. Wicked environmental problems. In The Companion to Environmental Studies; Hulme, M., Ed.; Cambridge University Press: Cambridge, UK, 2017.

50. Funtowicz, S.; Ravetz, J. Science for the post-normal age. Futures 1993, 25, 739-755. [CrossRef]

51. Funtowicz, S.; Ravetz, J. Post-Normal Science. 2013. Available online: http://isecoeco.org/pdf/pstnormsc. pdf (accessed on 8 December 2017).

52. De Dianous, V.; Fiévez, C. Aramis project: A more explicit demonstration of risk control through the use of bow-tie diagrams and the evaluation of safety barrier performance. J. Hazard. Mater. 2006, 130, 220-233. [CrossRef] [PubMed]

53. Norio, O.; Ye, T.; Kajitani, Y.; Shi, P.; Tatano, H. The 2011 eastern japan great earthquake disaster: Overview and comments. Int. J. Disaster Risk Sci. 2011, 2, 34-42. [CrossRef]

54. Gill, J.C.; Malamud, B.D. Hazard interactions and interaction networks (cascades) within multi-hazard methodologies. Earth Syst. Dyn. 2016, 7, 659-679. [CrossRef]

55. Gill, J.C.; Malamud, B.D. Anthropogenic processes, natural hazards, and interactions in a multi-hazard framework. Earth-Sci. Rev. 2017, 166, 246-269. [CrossRef]

56. Kumasaki, M.; King, M.; Arai, M.; Yang, L. Anatomy of cascading natural disasters in japan: Main modes and linkages. Nat. Hazards 2016, 80, 1425-1441. [CrossRef]

57. Lofstedt, R.; Bouder, F.; Wardman, J.; Chakraborty, S. The changing nature of communication and regulation of risk in europe. J. Risk Res. 2011, 14, 409-429. [CrossRef]

58. Young, O. The Institutional Dimensions of Environmental Change: Fit, Interplay and Scale, 1st ed.; MIT Press: Cambridge, UK, 2002.

59. Corfee-Morlot, J.; Cochran, I.; Hallegatte, S.; Teasdale, P.J. Multilevel risk governance and urban adaptation policy. Clim. Chang. 2011, 104, 169-197. [CrossRef]

60. Adachi, T.; Ellingwood, B. Serviceability of earthquake-damaged water systems: Effects of electrical power availability and power backup systems on system vulnerability. Reliab. Eng. Syst. Saf. 2008, 93, 78-88. [CrossRef]

61. Gill, J.; Malamud, B. Reviewing and visualizing the interactions of natural hazards. Rev. Geophys. 2014, 52, 680-722. [CrossRef]

62. Komendantova, N.; Mrzyglocki, R.; Mignan, A.; Khazai, B.; Wenzel, F.; Patt, A.; Fleming, K. Multi-hazard and multi-risk decision-support tools as a part of participatory risk governance: Feedback from civil protection stakeholders. Int. J. Disaster Risk Reduct. 2014, 8, 50-67. [CrossRef] 
63. Liu, Z.; Nadim, F.; Garcia-Aristizabal, A.; Mignan, A.; Fleming, K.; Luna, B. A three-level framework for multi-risk assessment. Georisk 2015, 9, 59-74. [CrossRef]

64. Mignan, A.; Scolobig, A.; Sauron, A. Using reasoned imagination to learn about cascading hazards: A pilot study. Disaster Prev. Manag. 2016 25, 329-344. [CrossRef]

65. Paté-Cornell, E. On "black swans" and "perfect storms": Risk analysis and management when statistics are not enough. Risk Anal. 2012, 32, 1823-1833. [CrossRef] [PubMed]

66. Jasanoff, S. The idiom of co-production. In States of Knowledge: The Co-production of Science and Social Order; Sheila, J., Ed.; Routledge: London, UK, 2004; pp. 1-13.

67. Jasanoff, S. Designs on Nature: Science and Democracy in Europe and the United States, 1st ed.; Princeton University Press: Princeton, NJ, USA, 2005.

68. Gluckman, P. The art of science advice to government. Nature 2014, 507, 163-165. [CrossRef] [PubMed]

69. Pielke, R. The Honest Broker: Making Sense of Science in Policy and Politics, 1st ed.; Cambridge University Press: Cambridge, UK, 2007.

70. Scolobig, A.; Linnerooth Bayer, J.; Ferlisi, S.; Cascini, L. Design and Testing: A Risk Communication Strategy and A Deliberative Process for Choosing a Set of Mitigation and Prevention Measures; IIASA: Laxenburg, Austria, 2011.

71. Ostrom, E. A general framework for analyzing sustainability of social-ecological systems. Science 2009, 325, 419. [CrossRef] [PubMed]

72. Duit, A.; Galaz, V.; Eckerberg, K.; Ebbesson, J. Governance, complexity, and resilience. Glob. Environ. Chang. 2010, 20, 363-368. [CrossRef]

73. Geels, F.W. Ontologies, socio-technical transitions (to sustainability), and the multi-level perspective. Res. Policy 2010, 39, 495-510. [CrossRef]

74. Österblom, H.; Gårdmark, A.; Bergström, L.; Müller-Karulis, B.; Folke, C.; Lindegren, M.; Casini, M.; Olsson, P.; Diekmann, R.; Blenckner, T.; et al. Making the ecosystem approach operational—Can regime shifts in ecological- and governance systems facilitate the transition? Mar. Policy 2010, 34, 1290-1299. [CrossRef]

(C) 2017 by the authors. Licensee MDPI, Basel, Switzerland. This article is an open access article distributed under the terms and conditions of the Creative Commons Attribution (CC BY) license (http://creativecommons.org/licenses/by/4.0/). 